\title{
LEGAL AUTOPOIESIS AND THE CAPITAL/REVENUE DISTINCTION
}

\author{
Wai Boh Ding*
}

\begin{abstract}
This paper attempts to use the theory of legal autopoiesis to understand the struggle the courts have experienced when asked to decide tax cases involving the capital/revenue distinction, which is a distinction that could not be determined by any criteria. The theory of legal autopoiesis, as propounded by Niklas Luhmann, posits that the legal system, as an autopoietic system within society, produces and reproduces its own elements self-referentially and recursively. The legal system operates according to its code, which comprises the values 'legal/illegal'. The code is complemented and filled by programmes, which must be suitable and help to allocate the values in particular situations. However, if there are no programmes, how does the legal system allocate the values? The lack of a definite set of rules that can be used in tax cases to determine whether an item is capital or revenue in nature means that there is no programme according to which the legal system can allocate the values. This lack exposes a critical weakness in Luhmann's theory of legal autopoiesis.
\end{abstract}

\section{INTRODUCTION}

The capital/revenue distinction in tax law is a distinction that the courts have struggled to apply. In Inland Revenue Commissioners v John Lewis Properties Plc, ${ }^{1}$ Schiemann LJ lamented that "like others who are more at home in this field than I am, I have been unable to find a satisfactory conceptual distinction between capital and income which explains all the cases ..." 2 The distinction is one that "[j]udges and commentators have been complaining about ... for more than a century."3

* Submitted as part of the LLM programme at Victoria University of Wellington.

1 Inland Revenue Commissioners v John Lewis Properties Plc [2003] Ch 513 (CA).

2 Ibid, 550 Schiemann LJ.

3 Commissioner of Taxation v Citylink Melbourne Ltd [2006] HCA 35, para 20 (HCA) Kirby J. See also W Hemingway The NZ Land and Income Taxpayers' Guide (Hemingway and Robertson's Correspondence Schools Ltd, Auckland, 1917) 68 in which the author noted that the distinction was one of the most difficult questions to be decided in modern business. 
There is no single simple test that can be used to determine the distinction. ${ }^{4}$ If applied out of context, a test can even yield incorrect results. ${ }^{5}$

Why is the capital/revenue distinction, a distinction that has been used by the courts for more than a century, ${ }^{6}$ so difficult to apply? Can it be that the distinction itself is flawed? If it is flawed, can it be rectified so that its application is made easier? The distinction is a fundamental feature of any tax system that taxes income on an annual basis. A taxpayer's tax liability can be significantly affected by the proper characterisation of an item of receipt or expenditure. If an item of receipt is characterised as a capital item, the taxpayer is not liable to tax on that item. But if it is characterised as a revenue item, then the taxpayer is liable to pay tax. ${ }^{7}$ Tax cases requiring the determination of the distinction often involve large sums of money. The determination of such cases therefore has significant revenue implications for either the revenue authority or the taxpayer.

4 Her Majesty's Revenue \& Customs Business Income Manual, BIM35005 www.hmrc.gov.uk (accessed 1 July 2007). See also Van den Berghs Ltd v Clark [1935] AC 431, 438 (HL), in which Lord Macmillan said that "no infallible criterion" has emerged which could be used to determine whether an item is capital or revenue in nature, and Strick v Regent Oil Co Ltd [1966] AC 295, 313 (HL), in which Lord Reid said that "no one test or principle or rule of thumb is paramount" when it comes to determining whether an item is capital or revenue in nature.

5 United Kingdom Revenue \& Customs Business Income Manual, ibid.

6 See generally Walter Strachan "Economic and Legal Differentiation of Capital and Income" (1910) 26 LQR 40, and John McDermott and John Prebble "Circulating Capital: A Judicial Label" (paper presented at the 15th Annual Australasian Tax Teachers Association Conference, University of Wollongong, 30 January to 1 February 2003).

7 The proper characterisation of an item of expenditure can also significantly affect a taxpayer's tax liability. If an item of expenditure is characterised as a capital expenditure, then the taxpayer is not entitled to claim deduction for it. But if it is characterised as a revenue expenditure, then the taxpayer is entitled to claim deduction for it; the ability to claim deduction for an item of revenue expenditure allows the taxpayer to reduce his or her taxable income. Capital receipts are receipts that come from the sale or disposal of a taxpayer's permanent or fixed assets; for example, proceeds paid for a freezing works (CIR $v$ Thomas Borthwick \& Sons (Australasia) Ltd (1992) 14 NZTC 9,101 (CA)); and proceeds paid to rescind a long-term contract (Van den Berghs Ltd v Clark, above n 4). Revenue receipts are receipts that come from the sale or disposal of a taxpayer's circulating assets; for example, receipts from the sale of the taxpayer's trading stock. Capital expenditure is expenditure incurred by a taxpayer to acquire or replace a permanent or fixed asset; for example, expenditure incurred in replacing a trotting track (Auckland Trotting Club v CIR [1967] NZLR 193 (HC)); expenditure incurred by a power company in replacing overhead power lines with underground cables (Hawkes Bay Power Distribution Ltd v CIR (1998) 18 NZTC 13,685 (HC)); and expenditure incurred by a taxpayer to improve the seismic strength and structural integrity of a building (Case X26 (2006) 22 NZTC 12,315 (TRA)). Revenue expenditure is expenditure incurred by a taxpayer to generate his or her income; such expenditure may relate to the maintenance of the taxpayer's permanent or fixed assets. Examples of revenue expenditure include expenditure incurred in renting the taxpayer's business premises, and expenditure incurred in hiring staff. 
This paper seeks to examine, from the perspective of the theory of legal autopoiesis as propounded by Niklas Luhmann, ${ }^{8}$ the struggle the courts have experienced in the determination of tax cases involving the capital/revenue distinction. The theory regards modern society as a system of communication. ${ }^{9}$ Within this system are various subsystems, such as the legal system, the political system, and the economic system. ${ }^{10}$ Each of these systems has its own unique communication, determined by the system's own code. ${ }^{11}$ According to Luhmann, the code of the legal system comprises the values "legal/illegal". ${ }^{12}$ Communications that invoke the values "legal/illegal" thus belong to the legal system. ${ }^{13}$ Further, each of these systems is operatively closed and, at the same time, cognitively open. ${ }^{14}$ Since these systems are operatively closed, they produce and reproduce their own operations self-referentially and recursively. No system can produce or contribute to the operations of other systems. What then is the relationship, if any, between these systems of communications? According to Luhmann, systems of communications are related to each other in the form of structural coupling. ${ }^{15}$ Structural coupling allows a system to be "irritated" by its environment ${ }^{16}$ and thus the chance to learn and transform its structures. ${ }^{17}$

This paper argues that the theory of legal autopoiesis, with its emphasis on systems' operative closure and structural coupling, offers a valuable insight into the courts' struggle with the application of the capital/revenue distinction in tax cases. Even though the courts have applied the capital/revenue distinction for more than a century, they have yet to come up with a test or a set of rules that can be used to determine whether an item of expenditure or receipt is capital or revenue in nature. This lack of a test or set of rules is astonishing, considering the legal system's emphasis on

8 Prior to his death in 1998, Niklas Luhmann was Emeritus Professor of Sociology at the University of Bielefeld, Germany.

9 Hugh Baxter "Autopoiesis and the 'Relative Autonomy' of Law" (1998) 19 Cardozo L Rev 1992, 1993; see also Gunther Teubner, Richard Nobles and David Schiff "The Autonomy of Law: An Introduction to Legal Autopoiesis" in James Penner, David Schiff and Richard Nobles (eds) Introduction to Jurisprudence and Legal Theory: Commentary and Materials (Butterworths, London, 2003) 897, 898.

10 Baxter, ibid

11 Teubner, Nobles and Schiff, above n 9, 898.

12 Niklas Luhmann Law as a Social System (trans Klaus A Ziegert, Oxford University Press, Oxford, 2004) 93-94.

13 Niklas Luhmann "Operational Closure and Structural Coupling: The Differentiation of the Legal System" (1992) 13 Cardozo L Rev 1419, 1428; Baxter, above n 9, 1993.

14 Baxter, ibid, 1993-1994.

15 Luhmann Law as a Social System, above n 12, 381; Luhmann "Operational Closure and Structural Coupling", above n 13, 1431-1434.

16 Luhmann Law as a Social System, ibid 382-383.

17 Luhmann "Operational Closure and Structural Coupling", above n 13, 1433. 
the certainty of law. If the law cannot be certain of its application, how can taxpayers go about organising their affairs confidently? The courts have, instead, repeatedly emphasised the need to consider all the circumstances of a case ${ }^{18}$ and to apply a common sense approach. ${ }^{19}$ The lack of a test or set of rules, coupled with the legal system's operative closure, mean that the determination of the capital/revenue distinction in tax cases is particularly difficult.

Part II of this paper presents a general discussion of the capital/revenue distinction in tax cases. It discusses briefly the historical background and development of the capital/revenue distinction. It then considers why the distinction is so difficult to apply.

Part III introduces the theory of legal autopoiesis as propounded by Niklas Luhmann. It traces in brief the development of the theory, the theory's origins in biology and its adaptation to the study of social systems. It considers the key concepts of operative closure and structural coupling in the theory, and some criticisms of the theory.

Part IV attempts to apply the theory to a recent tax case involving the capital/revenue distinction, the United Kingdom Court of Appeal's decision in Inland Revenue Commissioners $v$ John Lewis Properties Plc. ${ }^{20}$ It is contended that the theory offers a valuable insight into the courts' struggle with the application of the distinction. However, an examination of the courts' struggle, from the perspective of the theory, also provides an opportunity to examine the robustness of the theory itself. The lack of a test or set of rules, or in the terms of the theory, programmes, puts into question the operation of the legal system in allocating the code values "legal/illegal" in tax cases involving the capital/revenue distinction.

Part V concludes this paper. It suggests that while the theory of legal autopoiesis as propounded by Niklas Luhmann does offer a valuable insight into the courts' struggle with the distinction, the lack of a test or set of rules in the capital/revenue area in tax law, or in the terms of the theory, the lack of programmes, arguably exposes a weakness in Luhmann's theory of legal autopoiesis.

18 McClure v Petre [1988] 1 WLR 1386, 1389 (Ch) Sir Nicholas Browne-Wilkinson V-C. See also Hallstroms Pty Ltd v FCT (1946) 72 CLR 634, 648 (HCA) Dixon J, emphasising the "practical and business point of view."

19 See Strick v Regent Oil Co Ltd, above n 4; McClure v Petre, ibid, 1389 (Ch) Sir Nicholas BrowneWilkinson V-C; and BP Australia Ltd v FCT (1965) 112 CLR 386, 397 (PC) Lord Pearce.

20 Inland Revenue Commissioners v John Lewis Properties Plc, above $\mathrm{n} 1$. 


\section{THE CAPITAL/REVENUE DISTINCTION}

\section{A Introduction}

The capital/revenue distinction has been used by the courts for more than a century. ${ }^{21}$ However, there is still no single test that can be used in all cases to determine whether an item of expenditure or receipt is capital or revenue. The courts have only been able to provide guidelines, or indicators that may be used to determine whether an item is capital or revenue in nature. ${ }^{22}$

This part outlines first the legislative scheme that applies in New Zealand to the assessment of income and deduction of expenditure. It then sets out briefly the guidelines that the courts have provided to determine whether an item of expenditure or receipt is capital or revenue in nature. After this, it will consider why the capital/revenue distinction is so difficult to apply.

\section{B Legislation}

The Act that governs the taxation of income and deduction of expenditure is the Income Tax Act 2004.

\section{The taxation of income}

An amount is income if it is included in Part C of the Income Tax Act 2004. ${ }^{23}$ Such an amount is taxable unless it is exempt income, excluded income, or non-residents' foreign-sourced income. The term "income" is not defined in the Income Tax Act 2004.

The Act also includes amounts that are income under ordinary concepts. ${ }^{24}$ Since the Act does not define the term "income", what is and what is not income is to a large extent still determined by common law principles. ${ }^{25}$ In Scott $v$ CT (NSW), ${ }^{26}$ Jordan CJ stated that: ${ }^{27}$

21 See, for example, Re Armitage [1893] 3 Ch 337; Re Francis 92 LT 77; Re Searancke 74 LT 339; Re Ely [1904] I IR 66; Cowley v Wellesley 35 Beav 635; and Bates v Mackinley 31 LJ Ch 280.

22 See BP Australia Ltd v FCT, above n 19; and CIR v McKenzies NZ Ltd [1988] 2 NZLR 736 (CA).

23 Income Tax Act 2004, s CA1(1).

24 Income Tax Act 2004, s CA1(2).

25 John Veal, Therese Turner and Craig Macalister Staples Tax Guide 2006 (Brookers, Wellington, 2006) para 710. See also Stephen Barkoczy "Income According to Ordinary Concepts - Part 1: Mere Realisation or Business Operation?" (1997) 3 NZJTLP 75, 75, discussing the lack of a definition of income in an Australian context. The author noted that although the courts have continuously been confronted with the need to formulate a judicial definition of income, they have been reluctant to do so.

26 Scott v Commissioner of Taxation (NSW) (1935) 35 SR (NSW) 215.

27 Ibid, 219 Jordan CJ. 
The word 'income' is not a term of art, and what form of receipts are comprehended within it, and what principles are to be applied to ascertain how much of those receipts ought to be treated as income, must be determined in accordance with the ordinary concepts and usages of mankind, except in so far as the statute states or indicates an intention that receipts which are not income in ordinary parlance are to be treated as income or that special rules are to be applied for arriving at the taxable amount of receipts.

In Lambe $v$ CIR, ${ }^{28}$ the Court stated that:

[i]ncome may be of various sorts ... but nonetheless the tax is a tax on income. It is a tax on what in one form or another goes into a man's pocket.

In a speech to the New Zealand Institute of Chartered Accountants Tax Conference in 1997, the Rt Hon Sir Ivor Richardson noted the lack of a definition of income in the Income Tax Act 1994. ${ }^{29}$ Sir Ivor Richardson also noted that: ${ }^{30}$

There are tensions between the concepts of income held by economists and those of trusts and property law. Those tensions are not completely settled in the legislation and where they are settled a consistent pattern is not evident.

\section{The deduction of expenditure}

An amount is deductible if its deduction is permitted under Part D of the Income Tax Act 2004. Section DA 1 of the Income Tax Act 2004 sets out the general rule for determining when an amount is deductible. An amount of expenditure or loss is deductible if there is a nexus between the amount and the derivation of the taxpayer's or the business' assessable income, or excluded income, or a combination of both. The determination of the nexus or the extent of the nexus is left to the courts to decide and the guidelines that have been provided by the courts still apply.

Section DA 2 of the Income Tax Act 2004 lists the amounts that are not deductible. Included in that list are amounts that are of a capital nature. ${ }^{31}$ The term "capital" is not defined in the Act.

\section{Case Law Guidelines Relating to the Capital/Revenue Distinction}

As noted above, neither the term "income" nor the term "capital" is defined in the Income Tax Act 2004. Guidelines developed by the courts to determine whether an item of expenditure or

28 Lambe v CIR (1934) $1 \mathrm{~KB} 178$.

29 Sir Ivor Richardson "The Impact and Influence of Accounting and Economic Principles on Taxation Law" (1998) 4 NZJTLP 18, 18. See generally John Prebble "Income Taxation: A Structure Built on Sand" (2002) 24 Syd LR 301-318.

30 Richardson, ibid, 18.

31 Income Tax Act 2004, s DA2(1). 
receipt is capital or revenue in nature therefore still apply. Over the years, a considerable body of guidelines or principles has been developed by the courts.

Lord Pearce's speech in BP Australia Ltd v FCT ${ }^{32}$ is said to be "the governing approach" in New Zealand. ${ }^{33}$ In his speech, Lord Pearce collected and attempted to reconcile, or at least to rationalise, the leading Australian and United Kingdom judgments of the previous decades. ${ }^{34}$ In doing so, his Lordship mentioned most of the approaches that have found favour with the courts, and the facts that the courts have found to be material. ${ }^{35}$ His Lordship said: ${ }^{36}$

The solution to the problem is not to be found by any rigid test or description. It has to be derived from many aspects of the whole set of circumstances some of which may point in one direction, some in the other. One consideration may point so clearly that it dominates other and vaguer indications in the contrary direction. It is a commonsense appreciation of all the guiding features which must provide the ultimate answer. Although the categories of capital and income expenditure are distinct and easily ascertainable in obvious cases that lie far from the boundary, the line of distinction is often hard to draw in border line cases; and conflicting considerations may produce a situation where the answer turns on questions of emphasis and degree. That answer depends on what the expenditure is calculated to effect from a practical and business point of view, rather than upon the juristic classification of the legal rights, if any, secured, employed or exhausted in the process

As each new case comes to be argued, felicitous phrases from earlier judgments are used in argument by one side and the other. But those phrases are not the deciding factor, nor are they of unlimited application. They merely crystallise particular factors which may incline the scale in a particular case after a balance of all the considerations has been undertaken.

In CIR $v$ McKenzies New Zealand Ltd, ${ }^{37}$ the Court of Appeal extracted the following five indicia from Lord Pearce's speech to assist in determining whether an item of expenditure is capital or revenue in nature: ${ }^{38}$

32 BP Australia Ltd v FCT, above n 19

33 In CIR v Thomas Borthwick \& Sons (Australasia) Ltd (1992) 14 NZTC 9,101, 9,106, Richardson J stated that "the governing approach at least in New Zealand is exemplified in the observations of Lord Pearce in BP Australia Ltd v FCT ..." See also CIR v LD Nathan \& Co Ltd [1972] NZLR 209 (CA); Buckley \& Young Ltd v CIR (1978) 3 NZTC 61,271 (CA); CIR v McKenzies New Zealand Ltd (1988) 10 NZTC 5,233 (CA); Christchurch Press Co Ltd v CIR (1993) 15 NZTC 10,206 (HC); CIR v Wattie (1998) 18 NZTC 13,991 (PC); and Birkdale Service Station Ltd v CIR (2000) 19 NZTC 15,981 (CA).

34 McDermott and Prebble, above n 6, 4.

35 Ibid.

36 BP Australia Ltd v FCT, above n 19, 397 Lord Pearce quoting Dixon J in Hallstroms Pty Ltd v FCT (1946) 72 CLR 634, 648.

37 CIR v McKenzies New Zealand Ltd, above n 33. 
- The need or occasion that called for the expenditure;

- Whether the sums were made from fixed or circulating capital;

- Whether the payments were of a once and for all nature, creating assets or advantages that were of an enduring benefit;

- How the payment would be treated on ordinary principles of commercial accounting;

- Whether the payments were expended on the business structure of the taxpayer, or whether they were part of the process by which income was earned.

The above indicia can also be used to determine whether an item of receipt is capital or revenue in nature. ${ }^{39}$ Notwithstanding the above indicia, the courts have struggled to apply the capital/revenue distinction.

\section{Difficulty with the Capital/Revenue Distinction}

Why is the capital/revenue distinction so difficult to apply? In Commissioners of Inland Revenue $v$ British Salmson Aero Engines Ltd, ${ }^{40}$ the Master of the Rolls, Sir Wilfrid Greene, remarked that "in many cases it is almost true to say that the spin of a coin would decide the matter almost as satisfactorily as an attempt to find reasons." 41 And in Tucker v Granada Motorway Services Ltd, ${ }^{42}$ Templeman J stated that cases dealing with the distinction have created:

an intellectual minefield in which the principles are elusive ...; analogies are treacherous ...; precedents appear to be vague signposts pointing in different directions ...; and the direction finder is said to be 'judicial common sense' ... The practice of judicial common sense is difficult in revenue cases.

Why is it that after more than a century of applying the capital/revenue distinction in tax cases, the courts have yet to come up with a consistent, rule-based approach? Can it be that the distinction is itself flawed?

In an article entitled Ectopia, Tax Law and International Taxation, ${ }^{43}$ Professor Prebble described the capital/revenue distinction as "fundamentally flawed", 44 because it does not have a

38 Ibid, 5,236 Richardson J for the Court. See also Andrew J Maples "The Fixed and Circulating Capital Test: Down and Now Out in New Zealand?" (2005) 11 NZJTLP 315, 318.

39 CIR v Wattie, above n 33, 536.

41 Ibid, 498 Sir Wilfred Greene MR.

42 Tucker v Granada Motorway Services Ltd [1977] 1 WLR 1411.

43 John Prebble "Ectopia, Tax Law, and International Taxation" (1997) B T Rev 383.

44 Ibid, 395. 
basis in economic reality. ${ }^{45}$ Economists have known for years that the distinction is without a difference. ${ }^{46}$ It is not fundamental to natural law or economics, ${ }^{47}$ yet it is essential to any tax system that taxes income calculated on an annual basis. ${ }^{48}$ This is because the method of measuring income prescribed by most tax systems is a method that requires the division of income into segments that are delimited by time. This method is "antipathetic to the very concept of income, which is a continuous stream that has no natural or necessary relationship with the calendar." 49 There is no natural relationship between income and the calendar, but an income tax system cannot operate without artificially creating this relationship. ${ }^{50}$ A periodical system is therefore a practical imperative of an income tax regime. ${ }^{51}$ The period chosen is almost always a year, though there is no a priori reason why it should be so. ${ }^{52}$ The annual nature of income taxation leads inexorably to the distinction between capital and income, even though the distinction is artificial. ${ }^{53}$

The artificial nature of the distinction means that it is easy for taxpayers to avoid tax by converting income into capital. For example, a taxpayer holds a portfolio of shares that is pregnant with profits. The taxpayer has two options of realising the profits. They can either wait for a dividend to be declared, or sell the shares. If they choose to receive a dividend, then they are liable for tax on that dividend since it is an income item. But if they choose to sell the shares, then they are not liable for tax on the proceeds of the sale, which includes both the capital value of the shares and the potential dividend. ${ }^{54}$

The difficulty of distinguishing capital items from income items can be illustrated by considering the question of business premises. If a business leases its premises, it is entitled to deduct the rent that it pays from its receipts in calculating its taxable profits. If it buys the premises, it is not entitled to deduct the price, because the price represents a capital expenditure. The business is entitled to a deduction in the former case because the expenses (rents) relate to benefits that are

45 John Prebble "Ectopia, Formalism, and Anti-Avoidance Rules in Income Tax Law" in W Krawietz, N MacCormick and GH von Wright (eds) Prescriptive Formality and Normative Rationality in Modern Legal Systems: Festschrift for Robert S Summers (Duncker and Humblot, Berlin, 1994) 367, 378.

46 John Prebble "Why is Tax Law Incomprehensible" (1994) B T Rev 380, 388.

47 Ibid.

48 Ibid, 394.

49 Ibid.

50 Ibid.

51 Ibid.

52 Ibid.

53 Ibid.

54 Prebble, above n 45, 377. 
temporary, whereas in the latter case, the expenditure (purchase price) relate to benefits that are of a more enduring nature. However, business premises perform precisely the same function whether they are rented or purchased. ${ }^{55}$

The illustration above demonstrates the fictional and artificial nature of the capital/revenue distinction, which is a distinction that the courts have struggled to apply.

The next part of the paper introduces the theory of legal autopoiesis, and some key concepts in the theory.

\section{THE THEORY OF LEGAL AUTOPOIESIS}

\section{A Introduction}

The theory of legal autopoiesis was propounded and made popular primarily by two German sociologists and lawyers, Niklas Luhmann and Gunther Teubner. The theory has its genesis in biology. The term "autopoiesis" was coined by two Chilean biologists, Humberto Maturana and Francisco Varela, in the 1970s using two Greek words, "auto", and "poiesis", which means birth, creation or production. ${ }^{56}$ Hence the word "autopoiesis" means self-creation or self-production. The concept of autopoiesis was developed by Maturana and Varela because they were dissatisfied with the then existing answers to the question of "what is life". ${ }^{57}$ Maturana and Varela defined "life" as: 58

networks of processes of production of components that are continuously and recursively generated and realised as a concrete entity (unity) in the physical space, by the interactions of the same components that are produced as such a network.

Maturana and Varela typically use a single cell organism (such as an amoeba) to demonstrate the concept of an autopoietic entity. A cell is a network of molecular components in ongoing interaction - normally referred to as metabolism. ${ }^{59}$ However, metabolism does not explain life; it is merely a dynamic process that constitutes a network which produces the very same components. That process also produces a specific type of network that constitutes the system's spatial boundaries (for example, the membrane of a cell). ${ }^{60}$ As an autopoietic entity, a cell is therefore a system that

55 Ibid.

56 Jacob Arnoldi "Autopoiesis" (2006) 23 Theory, Culture and Society 116, 116

57 Ibid.

58 Humberto R Maturana "The Organizations of the Living: A Theory of the Living Organization" (1975) 7 International Journal Man-Machine Studies 313, 313.

59 Arnoldi, above n 56, 116.

60 Ibid. 
creates itself or "pulls itself up by its own bootstraps." 61 Metabolism and boundary formation happen simultaneously and are two sides of the same coin. ${ }^{62}$

Maturana and Varela distinguished organisation from structure. While autopoiesis is a certain form of organisation by which a system recursively produces its own elements and incorporates them into its own network, structure denotes a specific network at a specific time. Therefore, a system may have a certain form of organisation but its structure will change when certain elements are replaced. ${ }^{63}$ To Maturana and Varela, autopoietic systems are structure-determined systems and: ${ }^{64}$

\footnotetext{
Anything that happens in or to a system is determined by the system's structure at that specific point in time...

If a living system is autopoietic all of its operations - including any form of interaction with or response to its environment, that is, cognition in a broad sense - take place according to the structures that the system itself has built autopoietically. Things that happen in the environment can trigger structural changes in the system, but such structural changes, and any other response to outside information, are determined by the system's own structure.
}

The system only knows its own reaction to an external stimulus. ${ }^{65}$

Maturana and Varela's theory of autopoiesis was adapted by Luhmann for the study of social processes. The version developed by Luhman is located in a more comprehensive social-theoretical framework, that of social systems theory. ${ }^{66}$ The basic distinction among the many varieties of social systems theory is the distinction between a system and its environment. The open systems approach developed during the 1960s under the influence of advances in cybernetics and information theory is probably the best known systems theory to legal theorists. That approach emphasised the permeability or porousness of the boundary between system and environment: ${ }^{67}$

Inputs to and outputs from the system regularly cross the system boundary in a relation of 'exchange' or 'interchange' between system and environment. Through this process the system receives 'inputs' from its environment, processes them, and converts them into 'outputs' fed back to the environment. In turn,

61 Ibid; Humberto R Maturana and Francisco J Varela The Tree of Knowledge (Shambhala, Boston, 1998) 4647.

62 Arnoldi, above n 56, 116.

63 Ibid.

64 Ibid, 116-117.

65 RWM Dias "Autopoiesis and the Judicial Process" (1980) 11 Rechtstheorie 257, 274.

66 Baxter, above n 9, 1997-1998.

67 Ibid, 1998. 
information about the outputs' effects on the environment and the system flows back into the system, completing the 'feedback loop.'

As an example, consider the political system. ${ }^{68}$ "Desires" in the political environment press for entry into the political system. Some of these "desires" are expressed as "demands", which are inputted into the system. A fraction of the demands survive to the stage of system output - a decision that is fed back to the environment. The output of the political system may affect its environment, and information about the effects of the output is fed back into the system. The political system therefore has an open and adaptive relation to its environment - it may increase its adaptiveness by refining its "gatekeeping" mechanisms and improving its response to informational feedback.

It is apparent then that differentiated social systems within society, such as the legal system, the political system, and the economic system, are open to their environments only in a limited or qualified way. To the extent that the legal system operates according to its own standards and criteria, it will remain only selectively attentive to the processes of other social systems. ${ }^{69}$ According to Baxter: ${ }^{70}$

Luhmann's insight is to see this partial 'closure' of the legal system (and other systems) as intertwined with its openness to the environment. In Luhmann's paradoxical slogan: a system's closure is a condition of its openness. Or to put it more straightforwardly: in order to understand the relations among different social spheres, such as law and the economy, one must first understand their 'internal' operations. The language of input and output, however, is not designed to give such an account of a system's internal workings. Indeed, as Luhmann notes, it was developed precisely to sidestep that problem altogether.

For these reasons, Luhmann presents his autopoietic theory as a departure from more standard versions of systems theory. In Luhmann's work, the model of input and output gives way to an emphasis on systems' 'internal' operations.

The next part considers more closely the theory that was developed by Luhmann.

\section{B The Theory of Legal Autopoiesis}

The theory developed by Luhmann regards modern societies as "systems of communication that have become differentiated, through a process of social evolution, into various functional subsystems [such as] politics, religion, science, education, economy, and art, as well as the legal system." ${ }^{71}$ Each of these systems of communication has its own specialist language, and all "encode

68 Ibid.

69 Ibid, 2002-2003.

70 Ibid, 2003.

71 Ibid, 1993. 
the world in different ways. The legal system encodes the world into what is legal and illegal. Medicine encodes the world into what is healthy and unhealthy. Science encodes the world into what is true or false. Accountancy encodes the world into debits and credits. The economy perceives the world in terms of profits and losses." 72 The differences between these "systems of communication lie not in the task that they carry out, or the ideal that they appear to strive towards, but in the fact that they communicate about events using different codes." ${ }^{73}$ The code that each system uses determines the system's boundaries. ${ }^{74}$ Codes thus play an important role in Luhmann's theory of autopoiesis. Since a system's code results in its operative closure to communications that do not relate to its code, the system's operative closure also plays an important role in Luhmann's theory.

Luhmann maintains that, while an autopoietic system is operatively closed, nevertheless it is cognitively open, enabling the system to "observe" the environment. This ability of the system to observe is related to the system's programmes.

It should be noted that the theory of autopoiesis is "not concerned with the insulation of [a system] from [other systems]." ${ }^{75}$ Rather, it is concerned with "the conditions, mechanisms and consequences of mutual interference between [a system] and other systems."76

The code and programmes of a system, the system's operative closure and cognitive openness, and its structural coupling with other systems are thus important features in Luhmann's theory of legal autopoiesis.

\section{The Operative Closure and Code of the Legal System}

As noted above, Luhmann's theory regards modern societies as systems of communication that have become differentiated into various functional subsystems. As a system of communication, society consists simply of communication, and of every communication. ${ }^{77}$ Communications are both the elements of society and its operations. As operations of society, communications establish the system's boundaries. ${ }^{78}$ This achievement is established internally. Luhmann asserts that information has meaning to a system only in the terms of the system whose operations have produced it. Information is therefore system-specific. The operation of a system does not provide

72 Teubner, Nobles and Schiff, above n 9, 898.

73 Ibid.

74 Baxter, above n 9, 1993.

75 Teubner, Nobles and Schiff, above n 9, 10.

76 Ibid.

77 Baxter, above n 9, 2004.

78 Ibid, 2005. 
information to another system; rather, they present as "noise" to that other system. ${ }^{79}$ The extent to which a system may process the "noise" produced by another system as information to itself depends on its own internal structures and operations. ${ }^{80}$

Since communications are the elements and operations of society, and since society consists of functionally differentiated subsystems, such as the legal system and the political system, one might ask what difference is there, if any, between the communications of these functionally differentiated subsystems? The answer lies in the systems' codes.

As noted above, the code that the legal system uses comprises the values "legal/illegal". This code characterises a distinction that is specific to law. ${ }^{81}$ The code is a strictly internal structure. ${ }^{82}$ The values "legal/illegal" do not correspond to the sense in which they are used in criminal law. Rather, by "legal" Luhmann means a positive value and "illegal" a negative value. In tax law's terms, the value "legal" would mean having the legal effect that the taxpayer hopes or expects, and the value "illegal" would mean not having that effect. ${ }^{83}$ Tax cases involving the capital/revenue distinction provide a good illustration. Consider the case Fullers Bay of Islands Ltd $v$ CIR. ${ }^{84}$ The taxpayer had incurred certain legal expenses in proceedings against the Auckland Regional Council. The proceedings were issued as the taxpayer felt that it had been unfairly treated by the Council in relation to a tender process. The taxpayer claimed deduction for the legal fees that it had incurred. The claim was denied by the CIR on the ground that they were capital in nature. The Court of Appeal agreed with the CIR, holding that the contract to which the tender process related would, if it had been awarded to the taxpayer, have been a major addition to the taxpayer's business. The legal fees incurred were therefore properly regarded as capital in nature and not deductible. From the taxpayer's point of view, the value "legal" would mean revenue expenditure and therefore deductible, and the value "illegal" would mean capital expenditure and not deductible.

The code that the legal system uses determines the kind of communications that belong to the legal system. "Communication invoking the legal/illegal code belongs to the legal system; all other communication belongs to the legal system's environment." ${ }^{85}$ The autopoietic nature of the legal

79 Ibid, 2006.

80 Ibid.

81 Luhmann Law as a Social System, above n 12, 173.

82 Luhmann "Operational Closure and Structural Coupling", above n 13, 1427.

83 Geraldine Hikaka and John Prebble "Legal Autopoiesis and General Anti-Avoidance Rules" (paper presented at the 17th Australasian Tax Teachers' Association Conference, Victoria University of Wellington, 27-28 January 2005) 6.

84 Fullers Bay of Islands Ltd v CIR (2006) 22 NZTC 19,716 (CA).

85 Baxter, above n 9, 1993. 
system is an unavoidable outcome of the operations of the code, since only communications that invoke the code values belong to the legal system. The code also organises the structure of the legal system's operations. As an autopoietic system, the legal system is therefore "a recursive, selfreferential, self-producing, self-reproducing, self-observing, and self-describing system." 86 The theory that the legal system is an autopoietic system therefore treats the legal system as consisting of communications that invoke the code values "legal/illegal", not as a set of rules or a complex of institutions. ${ }^{87}$

\section{The Cognitive Openness, Programmes and Structural Coupling of the Legal System}

While the legal system is operatively closed, it is at the same time cognitively open to its environment. The legal system is able to observe its environment; however, its observations are always conditioned by its own: ${ }^{88}$

\footnotetext{
Premises, procedures, standards, and criteria ... The environment as it appears in legal communication is operatively constructed ... by the operations of the legal system itself, subject to the observational conditions the legal system's operations presuppose and reproduce. In this sense, the system's operative closure is the condition for its cognitive openness - i.e., its openness to the environment beyond the legal system's boundaries.
}

To Luhmann, the code of the legal system is "invariant", or unchanging. The code itself does not offer any way for the legal system to adapt to its changing environment, nor provide the legal system with criteria for the determination of legal and illegal. ${ }^{89}$ A legal system equipped only with the code "legal/illegal" would not be capable of operation. To enable the legal system to operate, the code needs a mechanism that will allocate either one of the two values "legal/illegal" to a particular event. This mechanism is "contained" in programmes, which are also structures within the legal system. Luhmann states that: ${ }^{90}$

[s]ince the values legal and illegal are not in themselves criteria for the decision between legal and illegal, there must be further points of view that indicate whether or not and how the values of the code are to be allocated rightly or wrongly. We shall call these additional semantic elements (in law and in other coded systems) programmes.

It follows that codes cannot exist by themselves. If an operation is brought under a code and so subsumed to a system, the question inevitably arises of which of the two values has to be attributed....

$86 \quad$ Ibid, 1994.
$87 \quad$ Ibid, 2007.
$88 \quad$ Ibid, 2010.
$89 \quad$ Ibid.
$90 \quad$ Luhmann Law as a Social System, above n 12, 192-195. 
codes are distinctions, which can only become autopoietically effective as distinctions with the help of a further distinction, namely the distinction between coding and programming. ... Only law's own programmes can ... specify what is correct. ... The programmes must be suitable to direct the allocation of the values legal and illegal. ...

The distinction between code and programmes is a "system-internal distinction". ${ }^{91}$ Programmes complement the code and fill it with content. ${ }^{92}$ Programmes include the whole of positive law constitutions, laws, regulations, court decisions, and contracts. ${ }^{93}$

Baxter explains the relationship between the legal system's code and its operative closure, and the relationship between its programmes and its cognitive openness thus: ${ }^{94}$

A system's coding accomplishes its operative closure and corresponds to the 'self-reference' side of the distinction between self-reference and external reference. A system's programming is the basis for its openness to the environment and its capacity for 'external' reference. A system is thus closed with respect to its code, but 'cognitively' open with respect to its programs. Coding and programming thus mutually presuppose one another and combine internal reference with external reference, closure with openness.

In Luhmann's theory, programmes are always conditional programmes: ${ }^{95}$

$[\mathrm{P}]$ rogrammes of the legal system are always conditional programmes. Only conditional programmes can instruct the continuous linking of self-reference and external reference; only conditional programmes provide the system's orientation to and from its environment with a form which is cognitive and at the same time which can be evaluated deductively in the system.

The rationale behind Luhmann's claim that programmes are always conditional programmes follows from his view that the role of the legal system is "to establish a combination of openness and closure, and external reference and self-reference." 96

The conditional program makes this combination explicit, referring in its 'then' clause to the systeminternal code and in its 'if' clause to the relevant event or process in the environment. Only the conditional program, Luhmann maintains, accomplishes an 'ongoing connection of self-reference and

91 Baxter, above n 9, 2010.

92 Luhmann Law as a Social System, above n 12.

93 Baxter, above n 9, 2011. See also Luhmann "Operational Clsoure and Structural Coupling", above n 13, 1434.

94 Baxter, ibid, 2011.

95 Luhmann Law as a Social System, above n 12, 196.

96 Baxter, above n 9, 2012. 
external reference,' giving 'the system's orientation to its environment a cognitive, and at the same time deductively usable form.'

Luhmann's assertion that autopoietic systems are closed systems does not mean that there is no relation between the various functionally differentiated autopoietic systems within society. On the contrary, the assertion means that a specific form of relations is required to account for the relations between the various autopoietic systems. ${ }^{97}$ In open systems theory, the form of relations is represented by the categories input and output. In autopoietic systems theory, however, the input/output model is replaced with the concept of structural coupling. ${ }^{98}$ The concept retains the idea of highly selective connections between systems and environments. Structural couplings connect systems through system structures ${ }^{99}$ and are forms of simultaneous relations. ${ }^{100}$ By replacing the input/output model with the concept of structural coupling, the idea that information can enter a system from the outside is therefore excluded. "Information" from the outside is now perceived as noise to the system. Communications occurring in one system appear not as information to another system but as noise. The noise may irritate the system and register in the system's communication. When this happens, the system may process the noise into information within the system's communication. Baxter explains further: ${ }^{101}$

[S]tructural coupling has two sides - it excludes as well as includes, and separates as well as connects. Structural couplings both 'provide a continuous influx of disorder against which the system maintains or changes its structure' and, at the same time, they exclude most 'environmental facts from immediate relevance.' Structural couplings both 'admit irritation' and allow systems to 'remain indifferent' to the great bulk of each other's communications.... Structural coupling is not fusion.

Structural coupling enables mutual and reciprocal observation among autopoietic systems. ${ }^{102}$ For example, property connects the legal system to the economic system and enables the legal system to observe, through a property schema that connects various economic interests to the bundle of legally recognised rights, the economic system. It also enables the economic system to observe, through a property schema of its own, the legal system.

Courts occupy a central position in Luhmann's theory. This is because they are legally obliged to render legal decisions, thus placing them in the position of "paradox managers". Rendering legal

97 Luhmann Law as a Social System, above n 13, 1431.

98 Ibid, 1432.

99 Baxter, above n 9, 2038

100 Luhmann Law as a Social System, above n 13, 1432

101 Baxter, above n 9, 2038-2039.

102 Ibid, 2050. 
decisions involving legal argument is an important means of maintaining the legal system's autopoietic nature: ${ }^{103}$

Legal argument ... presents the courts with alternative paths for decision; it frames the issues for decision by excluding most of the legal environment (and for that matter, most legal communication) as irrelevant, and it connects courts' decisions to past and future legal decisions. Legal argument thus helps reproduce the legal system as a network of communication.

\section{APPLICATION TO A TAX CASE INVOLVING THE CAPITAL/REVENUE DISTINCTION}

This part of the paper attempts to apply Luhmann's theory of legal autopoiesis to a recent tax case involving the capital/revenue distinction. Even though the theory has been highly influential in Europe, ${ }^{104}$ it remains a "very controversial and sometimes misunderstood theory especially within the English speaking world." 105 Many Anglo-American social and legal scholars see it as a "somewhat obscure and hardly comprehensible doctrine." 106 Some have described it as "an example of how not to go about theory construction." 107 Ultimately, however, the value of the theory to an understanding of the legal system depends not just on its description of the legal system in general, but also on its application to specific areas of law.

Income tax law has been described as "an almost textbook example of autopoiesis." 108 This is because income tax law, being dislocated from its subject matter, displays the qualities of operative closure, recursiveness, and self-reproduction that Luhmann sees in the legal system in general. ${ }^{109}$ The dislocation of income tax law from its subject matter has been described as ectopic in nature. ${ }^{110}$ One of the contributing reasons for the ectopia of income tax law is that income tax law is based on a number of fictions, including counter-factual fictions. The primary example of a counter-factual fiction is the capital/revenue distinction, which assumes that there is a logical, real world distinction

103 Ibid, 2034-2035.

104 Ibid, 1992. See generally Jacob Arnoldi "Niklas Luhmann: An Introduction" (2001) 18 Theory, Culture and Society 1.

105 Jiří Přibáň and David Nelken "Introduction" in Jiř́ Přibáň and David Nelken (eds) Law's New Boundaries: The Consequences of Legal Autopoiesis (Ashgate, Aldershot, 2001) 1. See also Gunther Teubner "How the Law Thinks: Toward a Constructivist Epistemology of Law" (1989) 23 Law and Society Review 727-752.

106 Přibáň and Nelken, ibid, 1. See generally Teubner, ibid.

107 MBW Sinclair "Autopoiesis: Who Needs It?" (1992) 16 Legal Studies Forum 81, 98.

108 Hikaka and Prebble, above n 83, 35.

109 Ibid, 15.

110 See generally Prebble "Ectopia, Tax Law and International Taxation", above n 43; and Prebble "Ectopia, Formalism and Anti-Avoidance Rules in Income Tax Law", above n 45. 
between capital and revenue. ${ }^{111}$ Counter-factual fictions trigger recursive, self-referential judicial reasoning, which is best seen in cases on the distinction between capital and revenue. ${ }^{112}$ For example, in Tucker $v$ Granada Motorway Services $L t d,{ }^{113}$ Lord Wilberforce felt obliged to treat a lease as a capital asset because that is the way that tax law treats leases, notwithstanding that the lease in question was of negative value, could not appear in the taxpayer's balance sheet, and was non-assignable.

This paper attempts to examine, from the perspective of the theory of legal autopoiesis, the United Kingdom Court of Appeal case of Inland Revenue Commissioners v John Lewis Properties Plc. ${ }^{114}$ The case displays the qualities that are emphasised by the theory - the operative closure and cognitive openness of the legal system, and the system's self-referential and recursive reasoning. Examining the case from the perspective of the theory also reveals a need to reconsider the operation of the legal system in situations where there is a lack of programmes that are suitable to allocate the code values "legal/illegal".

\section{A Inland Revenue Commissioners v John Lewis Properties Plc}

1 Facts

The facts of the case can be briefly stated. The taxpayer company, John Lewis Properties Plc, was the property holding company for the John Lewis Partnership group of companies. It owned the freehold or long leasehold interest in some five substantial properties, which it leased to John Lewis $\mathrm{Plc}$, the trading company of the group.

In 1995, the taxpayer entered into a tax saving scheme proposed by a Dutch bank, Rabobank. Pursuant to the scheme, the taxpayer executed a deed of assignment by which it agreed to assign to the bank the right to receive the rents payable by John Lewis Plc for the period from 23 January 1996 to 23 January 2001. In return for the agreement to assign, the bank paid the taxpayer a lump sum of $£ 25 \mathrm{~m}$, which was equivalent to the discounted value of the rents on the date of the assignment. The aim of the scheme was to enable the taxpayer to obtain, in place of the rents for which it would have had to pay tax, "a capital receipt which in economic substance was the equivalent of an amortising loan ... repayable by instalments equal in amount to the assigned rents over the five-year period." 115

111 Hikaka and Prebble, above n 83, 16.

112 Ibid, 17.

113 Tucker v Granada Motorway Services Ltd, above n 42.

114 Inland Revenue Commissioners v John Lewis Properties Plc, above n 1.

115 Inland Revenue Commissioners v John Lewis Properties Plc [2002] 1 WLR 35, 38 (Ch) Lightman J. 
After the assignment, the trading company, John Lewis Plc, together with the taxpayer, claimed roll-over relief for expenditure incurred by the trading company; the expenditure incurred was equal to the bulk of the lump sum paid by the bank to the taxpayer.

The revenue authority rejected the claim and assessed the taxpayer for corporation tax for the period ending 31 January 1996 in the amount of $£ 31 \mathrm{~m}$ on the ground that the lump sum paid by the bank was an income and not a capital receipt.

The taxpayer appealed successfully to the Special Income Tax Commissioner. The revenue authority then appealed to the High Court.

\section{High Court Decision}

The High Court dismissed the appeal by the revenue authority, ${ }^{116}$ holding that the receipt from the bank was capital in the hands of the taxpayer and not income in nature. In his discussion on the capital/revenue issue, Lightman $\mathrm{J}$ began by acknowledging the need to consider, from a practical and business point of view, what an item of expenditure was calculated to effect. ${ }^{117}$ His Honour then turned to guidelines provided by previous case law, stating that: ${ }^{118}$

[t]he authorities offer as a guide the principle that a receipt for the recurrent produce of an asset and compensation for the loss of such produce or to make good a hole in the receipts from such produce constitute income, whilst a receipt for the asset or part of the asset or for the permanent impairment or sterilisation of an asset constitutes capital.

Lightman J's acknowledgement of the need to consider from a practical and business point of view, followed immediately by his turn to previous case law, demonstrates the law's cognitive openness (external reference) and operative closure (self-reference). His Honour's turn to previous case law led him into a self-referential and recursive reasoning.

After considering previous case law, his Honour stated that the question was whether he should follow the principle stated by Lord Romer in Paget $v$ Inland Revenue Commissioners, ${ }^{119}$ that the proceeds of a sale of a right to receive income in the future could not be treated as income for income tax purposes. As Paget was a decision of the Court of Appeal, his Honour was bound to follow it. His Honour stated that the guidance provided by Lord Hoffmann in MacNiven $v$ Westmoreland Investments $L t d^{120}$ supported the approach taken by Lord Romer. His Honour held that the taxpayer was perfectly entitled, for the avoidance of tax, to structure its commercial

116 Ibid.

117 Ibid, 43 Lightman J.

118 Ibid.

119 Paget v Inland Revenue Commissioners [1938] 2 KB 25 (CA).

120 MacNiven $v$ Westmoreland Investments Ltd [2001] UKHL 6. 
transaction with the bank so that in place of an income receipt of rent, it received a capital sum. There was no broad "economic equivalence test" entitling the court to treat a capital item as income because it was the economic equivalent of income.

Lightman J's holding demonstrates the operative closure of the law. The law determines the character of a receipt based on its criteria, not on what the receipt is economically equivalent to. His Honour stated that he reached his conclusion with reluctance, and expressed sympathy for the approach taken by the revenue authority: $:^{121}$

I reach this conclusion with reluctance. I have sympathy with the approach of the revenue that the price obtained for a temporary disposal of "the fruit of a tree" or of the produce of an income producing asset should be taxed as income. ... The approach has the attraction that it will strike down attempts to exploit devices to exempt from income tax which can only have the effect of transferring the tax burden on to others. ... A premium paid for a lease is capital even though in reality it may only constitute and be calculated as a prepayment of rent. So also is the price in this case.

\section{Court of Appeal Decision}

Following the High Court's decision, the revenue authority appealed to the Court of Appeal. By a majority of 2:1, the Court of Appeal dismissed the appeal.

Dyson LJ, with whose judgement Schiemann LJ agreed, upheld the High Court's decision that the payment was a capital item. His Honour began his judgement by acknowledging the difficulty the courts have had in dealing with tax cases involving the capital/revenue distinction. His Honour stated: ${ }^{122}$

The question whether a payment is to be regarded as capital or income has troubled the courts for a very long time. There are statements of the highest authority which indicate that classification cannot be made by the application of something akin to a simple litmus test. Various guidelines have been given from time to time. But it has repeatedly been emphasised that much depends on the nature of the transaction and the matrix in which it is set.

Dyson LJ's opening statements echoed the remarks made by Lord Pearce in the BP Australia case. ${ }^{123}$ While certain guidelines have been developed by the courts, the determination of whether

121 Inland Revenue Commissioners v John Lewis Properties Plc, above n 115, 51 Lightman J.

122 Inland Revenue Commissioners v John Lewis Properties Plc, above n 1, 541. Dyson LJ also referred to the statement by Lord MacMillan in Van den Berghs Ltd $v$ Clark, above $\mathrm{n} 4$, that "no infallible criterion emerges" which could be used to determine whether an item is capital or revenue in nature, and the statement by Lord Wilberforce in Strick v Regent Oil Co Ltd, above n 4, that the tests which the courts have developed in past cases "may be useful, so long as it is recognised that they have emerged a posteriori from the facts of a given situation and that they may not always be suitable as guiding lines in other situations."

123 BP Australia Ltd v FCT, above n 19. 
an item is capital or revenue in nature does not depend on a rigid application of any of the guidelines. Rather, it depends on a consideration of all the relevant features of the surrounding circumstances. Some features may point clearly in one direction that they dominate other features that point to the opposite direction. In Lord Pearce's words, it is a question of "emphasis and degree." 124

Dyson LJ then referred to various passages in the Strick $v$ Regent Oil Co Ltd case, before setting out the five factors which he considered were relevant to the question that the Court had to determine. The first factor was duration. ${ }^{125}$ If an asset has an enduring or long-lasting quality, then the courts are likely to treat it as a capital asset, and any payment associated with it is treated as a capital receipt. However, an asset that does not have an enduring quality may be treated as a capital asset if, in the context of the trade in question, it is appropriate to treat it as such.

The second and third factors that Dyson LJ considered relevant were the value of the asset assigned, ${ }^{126}$ and any diminution in the value. If the value of the asset assigned is substantial, then it is likely to be treated as a capital item. ${ }^{127}$ If, as a result of the assignment, there is a diminution in the value of the asset, then the payment for the assignment is a capital receipt. The diminution does not have to be permanent.

124 Ibid, 397 Lord Pearce.

125 It is somewhat puzzling that Dyson LJ had considered duration as relevant to the question before the Court, given that his Honour had noted the observation made by Lord Wilberforce in the Regent Oil case that there was no basis for determining the character of an asset, that is, whether capital or revenue, based on the duration of the asset - "[Lord Wilberforce] went on to say that he could see no logical basis for saying that 21 or 10 years was good enough to qualify as capital, but three or five years was too short, or for saying that five years or three years may be long enough when there is a lease, and not long enough where there is merely a personal covenant." Inland Revenue Commissioners v John Lewis Properties Plc, above n 1, 544 Dyson LJ.

126 The second factor has been criticised as "totally irrelevant" to whether the payment was capital or revenue in nature. See Graeme MacDonald "IRC v John Lewis Properties Plc: Cutting the Gordian Knot of 'Income or Capital"' (2003) B T Rev 203, 204.

127 The character of the value, that is, whether capital or revenue, is usually determined by the character of the asset. If the asset is capital, then the value is capital and if the asset is revenue, then the value is revenue. The character of the value is not independent of the character of the asset. It is unclear why Dyson LJ had regarded the value of the asset as a relevant factor. His Honour referred to the speech of Lord Upjohn in Strick v Regent Oil Co Ltd, above n 4, 345-346 in which Lord Upjohn said that "the amount of the payment and the length of the tie are important elements among all the other relevant facts. ... The lump sum payments here are large. But one must not attribute to that too much importance because after all the lump sum payment is calculated on the basis that it represents no more than one penny per gallon on the expected sales over the length of the tie." Lord Upjohn treated the 21-year ties in that case as capital items and the five-year ties as revenue items ("merely long term trading contract"). Arguably, the character of the asset is more important to Lord Upjohn than the amount or value associated with the asset. 
The fourth factor mentioned by Dyson LJ was whether the payment was a one-off payment, or whether it was one of a series of recurring payments made at frequent intervals. If it was a one-off payment, then it was likely to be a capital receipt but if it was one of a series of recurring payments, then it was likely to be a revenue receipt.

The fifth and last factor mentioned by Dyson LJ was whether there was a transfer of risk accompanying the disposal of the asset. If there was, then the payment made for the disposal is likely to be a capital receipt.

The five factors that Dyson LJ considered were relevant to the question before the Court demonstrate the operative closure and cognitive openness of the law. For example, the first factor, duration, shows that it is the law that decides whether an asset is capital or revenue in nature. If an asset has an enduring quality, then the law treats it as a capital asset, regardless of the economic effect of the asset. The law is bound to treat such assets as capital assets because this is how past cases have treated such assets; in other words, the law engages in self-referential and recursive reasoning in treating assets with an enduring quality as capital assets. However, the law recognises (that is, the law is cognitively open to the concept) that some assets, though not having an enduring quality, should nevertheless be treated as capital assets because it is appropriate to treat them as such in the context of the trade in question.

The second and fourth factors also demonstrate the operative closure of the law. If the value of the asset assigned is great, then the law treats it as a capital item, even though economically it may be equivalent to a revenue item. The treatment of the value of an asset is determined by the law itself, not by what the value is economically equivalent to. If the payment is a one-off payment, then the law is likely to treat it as a capital item, but if it is one of a series of payments, then it is a revenue item.

The fifth factor, the transfer of risk, demonstrates the cognitive openness of the law. The law observes whether the disposal of an asset is accompanied by a transfer of risk. In other words, the law observes whether there is commercial reality in the disposal. If there is, then the payment received for the disposal is a capital receipt. While this factor demonstrates the cognitive openness of the law, it also calls into question the operative closure of the law. Does the law determine the character of a payment based on its own criteria, or based on criteria in the economic system (whether there is commercial reality and whether there is a transfer of risk)? Arguably, this factor, which was mentioned in a case concerned with tax avoidance, ${ }^{128}$ assumes more importance if there is allegation that the taxpayer had deliberately converted a generally taxable revenue receipt into a generally non-taxable capital receipt.

128 MacNiven $v$ Westmoreland Investments Ltd, above n 127, para 54 Lord Hoffmann. His Honour said that the lack of commercial reality would not "perform the alchemy" of transforming a revenue receipt into a capital receipt; the revenue receipt remains as such. 
Further comments made by Dyson LJ in his judgement also demonstrate the operative closure of the law. For example, his Honour said that "the fact that [a lump sum] is equivalent to the value of six years' rent discounted for early receipt tells one little or nothing about whether the lump sum is capital or income." ${ }^{129}$ In other words, the law does not treat a lump sum according to its economic equivalence. Later in his judgement, his Honour said: ${ }^{130}$

The relevant question is: what was the lump sum paid by the bank in the hands of [the taxpayer]? It is true that the payment was for future income. But it does not follow that the payment was of the same character as the future income for which it was made. It seems to me that so to characterise the lump sum payment is to make the mistake of confusing the measure by which the payment is calculated with the payment itself.

Thus, the amount of a payment may be determined by reference to a stream of future rental payments; however, that does not mean that it will be treated in law as a revenue payment. If the payment is associated with a capital asset, then it is a capital payment.

Applying the five factors that he had identified as relevant to the question before the Court, Dyson LJ held that the payment received by the taxpayer was a capital receipt. His Honour acknowledged that in reaching his conclusion, he had been influenced by the consideration that if the taxpayer had granted a lease to the bank, the premium paid by the bank would have been treated as a capital receipt. Dyson LJ's approach clearly demonstrates the operative closure of the law - the law decides the character of a payment based upon the criteria that it has developed. The criteria are, however, mere guidelines; some may be more useful and may assume more importance in a case than others. They are not rules that can be applied to all cases and circumstances. Dyson LJ recognised this when he emphasised that the five factors were relevant only to a case such as the one with which he was dealing. ${ }^{131}$

The dissenting judgement was delivered by Arden LJ. Like Lightman J in the High Court, Arden LJ began her judgment by acknowledging the need to consider the issue from a practical and business point of view. Her Honour then turned immediately to a consideration of previous case law

129 Inland Revenue Commissioners v John Lewis Properties Plc, above n 1, 547 Dyson LJ.

130 Ibid, 548 Dyson LJ. See also his Honour's comments when he rejected the submissions by counsel for the Commissioner that the payment received by the taxpayer was a payment for future income - it operated as a substitute for future rents and represented a conversion of future income into present income. His Honour did not accept that the payment was therefore a revenue receipt.

131 Before setting out the five factors, his Honour said, "I would identify the following factors in a case such as the present as being relevant to the question whether a payment is capital or income. I emphasise 'such as the present' because the guidance derived from cases dealing with one situation may have little application to a wholly different situation." Ibid, 544 Dyson LJ. 
on the capital/revenue distinction. In her consideration of the group of cases which, according to her Honour, illustrate the realisation principle, Arden LJ made the following comments: ${ }^{132}$

I accept that the sale of a single year's payment of an annuity might fall within the realisation principle even though it is only a partial realisation of the asset since that part of the asset is then disposed of. On the other hand, it would not always do so. In the case where the annuitant is entitled to, say, six monthly payments of annuity I do not consider that he could necessarily avoid income tax by selling his right to a six months' instalment for a lump sum to a third party. I thus distinguish between an annuity (or part of an annuity) and instalments of annuity. I also distinguish between an interest coupon and payments of interest thereon. The annuity and the interest coupon are assets from which income is derived and are entire in themselves.

Her Honour's comments demonstrate again the operative closure of the law, which is a feature emphasised by the theory of legal autopoiesis. The operative closure of the legal system led Arden $\mathrm{LJ}$ to distinguish an annuity from the instalments of annuity, and an interest coupon from the payments of interest on the coupon. The differences that Arden LJ made were only meaningful and significant in law. After all, the instalments of annuity are exactly what a beneficiary of an annuity will receive. Similarly, the interest payments on an interest coupon are exactly what a holder of an interest coupon will receive. What a beneficiary of an annuity receives, and what a holder of an interest coupon receives, bears a different character in law from what they each holds.

Turning to a consideration of the lump sum payment received by the taxpayer, Arden LJ said: ${ }^{133}$

I consider that the right to receive rent is analogous to a payment or instalment of an annuity rather than to a part of the annuity itself. ... The right to receive rent is thus not analogous to an annuity, which is entire in itself

This led her Honour to conclude that the payment received by the taxpayer was a revenue receipt.

Further comments made by Arden LJ also demonstrate the operative closure of the law. For example, in her consideration of the cases concerning premiums on leases, her Honour said: ${ }^{134}$

A premium payable by a tenant on taking a lease has been treated in law as a sum paid in order to obtain a capital asset in the form of a new lease, and thus as constituting a capital payment by the tenant. This is so even if the amount of the premium has been calculated by reference to the prospective rent.

Arden LJ held that the character of the lump sum payment received by the taxpayer could not be decided by a comparison with the cases on premiums: ${ }^{135}$

132 Ibid, 526 Arden LJ.

133 Ibid, 526 Arden LJ.

134 Ibid, 527-528 Arden LJ. 
... [the taxpayer] has not, in my judgment, in reality realised an element of the capital value of its property but has disposed of some of the income which it produces or will produce in future. Thus the present case is not on all fours with the cases on premiums.

After considering previous English and Scottish cases on the capital/revenue distinction, Arden LJ extracted the following points: ${ }^{136}$

- Every case depends on a careful examination of the particular circumstances. The decision whether a receipt (or item of expenditure) is capital or income is highly fact-sensitive.

- $\quad$ "Capital" and "income" are commercial concepts. The test is one of commercial reality; technical juristic distinctions are of little relevance.

- The underlying asset from which the sum is derived may have a large influence on whether the payment is capital or income.

- The court asks whether, as a matter of practical and business reality, the asset transferred was the fruit or the tree on which the fruit hung.

- The sale of part of the asset does not always result in a capital receipt.

- The court also examines the nature of the payment. However, one must be wary of relying solely on the nature of the payment. The mere fact that it is a lump sum does not mean that it is capital.

- Recurrence is relevant in that it generally signifies income but income need not be recurrent. The mere fact that a receipt is a sum calculated by reference to trading profits does not mean that it is income, though it will often be.

Arden LJ stated that "[n]one of the [points listed above] is decisive, but they may indicate that a particular outcome is to be preferred." 137

In her conclusions, Arden LJ remarked that the lump sum payment received by the taxpayer did not perform "any different function in its economy from that which the rents would have performed if they had been discounted". ${ }^{138}$ According to her Honour, there were two telling factors in the case: the nature of the asset transferred, and the nature of the payment. The nature of the asset transferred consisted of the six rents plus the rights to recover the same. Those rents and those rights were income in the hands of the taxpayer. As to the nature of the payment, Arden LJ stated that the

135 Ibid, 529 Arden LJ.

136 Ibid, 533-534 Arden LJ.

137 Ibid.

138 Ibid, 537 Arden LJ. 
rentals in the present case were not simply a measuring stick - they were in reality the asset realised by the whole transaction. The amount of the proceeds represented the present value of the rent. ${ }^{139}$

Having determined the nature of the asset transferred and the nature of the payment made by the bank to the taxpayer, Arden LJ then turned to consider the business substance or commercial reality of the payment. Arden LJ stated: 140

In my judgment, in all the circumstances of this case, they must take their capital/income colour from the rentals which they represented. Instead of receiving rents as and when they fell due, [the taxpayer] simply realised them in a different way. The assignment is not to be disregarded. The fact, however, that the process involved the necessary interposition of a bona fide third party bank, which received the rents and paid the proceeds out of its own resources should not deflect the eye from the real nature of the transaction. ... The commercial reality of the assignment is that [the taxpayer] discounted the rents. It seems to me to follow that, whatever terminology the parties used in the deed of assignment, the commercial reality of what [the taxpayer] received was discounted rents and hence income. The transaction effected no change in [the taxpayer]'s programme of investment in properties. [The taxpayer] merely realised the six rentals in question in another way. What the transaction was intended to effect, from a practical and business point of view, was an accelerated payment of the rents, discounted for early payment. I cannot see that the proceeds should be capital any more than they would have been if [the taxpayer] has sold the rents each year for six years by six separate transactions.

... when the full circumstances are examined, the assignment did not as a commercial matter change the nature of the receipt from income to capital.

I consider that the proceeds of the assignment were, as a matter of business and commercial reality, income and not capital.

By emphasising the terms "in reality", the "real nature" of the transaction and the "commercial reality" of the assignment, Arden LJ appeared to have determined the character of the payment according to the "facts" of the economic system, even though her Honour had stated in her judgment that economic equivalence did not "play any part in this case: that would involve applying some broad functional test to establish the nature of the proceeds." 141 Though denying the application of some broad functional test, Arden LJ had, in her conclusions, remarked that the payment received by the taxpayer performed the same function as the rents which it was entitled to receive.

Arden LJ's conclusion, which was contrary to that reached by Dyson LJ, prompts one to consider whether the lack of a definite set of rules that can be applied to tax cases involving the

139 Ibid, 539 Arden LJ.

140 Ibid, 540 Arden LJ.

141 Ibid, 537 Arden LJ. 
capital/revenue distinction, and the emphasis in such cases on consideration of all relevant circumstances, consideration from a practical and business point of view, and applying judicial common sense in cases where the item of receipt or expenditure has not been considered in previous case law, allow the court to determine the character of the item by looking at how the item is treated in the economic system? In Luhmann's terms, do the lack of programme and the emphasis on cognitive openness in tax cases involving the capital/revenue distinction force the legal system to allocate the code values according to the "fact" as constructed in the economic system?

Compared with the conclusion reached by Dyson LJ, the conclusion reached by Arden LJ, that the payment received by the taxpayer was a revenue receipt, appears to be more persuasive. Her Honour recognised the fact that the payment made by the bank to the taxpayer represented the realisation of future rentals. The payment must therefore take its "colour" from the rentals.

\section{CONCLUSION}

This paper has attempted to examine the courts' struggle with the application of the capital/revenue distinction. The struggle is due firstly to the fact that the capital/revenue distinction itself is artificial and a fiction. The distinction is artificial because it does not have a basis in economic reality. It is a fiction because it presupposes that there is a logical, real world distinction between capital and revenue.

Secondly, from the perspective of the theory of legal autopoiesis, the courts' struggle is due to the operative closure of the legal system, and the lack of a definite set of rules that can be used to determine whether an item of receipt or expenditure is capital or revenue in nature. The operative closure of the legal system means that the system determines the nature of an item based on the criteria that it has developed, rather than on the economic reality of the item. The criteria, however, are only guidelines; they are not rules. The inability of the courts to come up with a definite set of rules means that there is no programme according to which the courts can allocate the code values "legal/illegal", or in terms of income tax law, the values "capital/revenue". The lack of a definite set of rules in the capital/revenue area in income tax law exposes a critical weakness in Luhmann's theory of legal autopoiesis. 